\title{
A microrregulação médica
}

José Mendes Ribeiro ${ }^{1}$

Em "Ensaio sobre o médico e suas valises tecnológicas" destaca-se logo de início uma imagem feliz acerca do trabalho cotidiano do médico frente a seu cliente. $\mathrm{O}$ emprego de três tipos de "valises", das quais uma diz respeito ao prolongamento de seus sentidos (estetoscópio, endoscópio etc); outra se refere ao modo como o médico estrutura seu pensamento e define os problemas (expresso

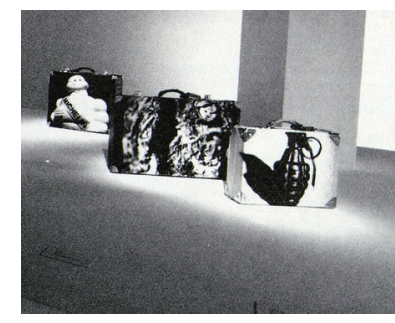
pela clínica e epidemiologia); e a última mais diretamente relacionada ao encontro entre indivíduos. Partindo desse arranjo, o autor analisa as interações entre indivíduos que definem e ordenam o conjunto da prática médica associadas às tendências observadas na esfera do mercado, onde são estruturadas as trocas e relações entre agentes. A cena clínica é vista como espaço de competição informada ou potencialmente informada estabelecida pelo cliente/usuário e o médico. Com esta estrutura analítica, entra no campo que define como o da micropolítica do processo de trabalho médico. A "valise" onde se estrutura a relação competitiva entre agentes/ sujeitos ("espaço relacional trabalhador-usuário") é enfatizada.

A ênfase na compreensão das relações entre indivíduos como fundamento da análise de processos é comumente tratada nas Ciências Humanas através das referências da Economia. No entanto, a freqüente insatisfação com o potencial explicativo da disciplina estimula os pesquisadores a adotarem modelos sociológicos (normas, valores, representações) ou políticos (estruturas, arranjos institucionais) no sentido de observar as relações entre agentes no contexto de grandes coletivos de indivíduos, de suas tradições e regras de convívio e leis. $\mathrm{O}$ autor destaca a competição pelo conhecimento (informação) entre médicos e clientes/usuários/beneficiários de serviços de saúde no contexto da "estruturação produtiva do setor" e da configuração do modelo de atenção. Como determinante deste processo aponta a lógica do capital financeiro como definidora da transição tecnológica (o equilíbrio entre as "três valises").

\footnotetext{
${ }^{1}$ Professor da Escola Nacional de Saúde Pública, Fundação Oswaldo Cruz, ENSP/Fiocruz.
} 
Aponta a crise da Medicina Tecnológica através da captura pelo capital financeiro (seguradoras) que atua no setor saúde sobre a decisão clínica, buscando subordiná-la a uma lógica gerencial. A atenção gerenciada seria, neste contexto, a expressão da reestruturação do mercado setorial, reordenando empregos e práticas médicas, assim como as expectativas dos usuários. Para o autor, este processo se dá de modo coerente ao que designa como uma competição entre "setores neoliberais" pela hegemonia setorial.

A análise acima resumida, espero que com razoável fidelidade, merece, pela importância do autor e pelas opiniões emitidas, alguns comentários sucintos no sentido de assegurar a continuidade do debate.

Como dito, a imagem das "valises" constituintes da prática clínica é feliz na medida em que permite mapear o protagonismo de cada componente em dada situação de trabalho e de relação com os clientes. Mais interessante ainda é o uso deste recurso para destacar a competição entre médicos e clientes no encontro clínico, onde a informação assimétrica e as estratégias compensatórias são objeto de políticas em diferentes sistemas sanitários.

Com relação ao ataque do capital financeiro à autonomia médica através da lógica gerencial, imagino que o desfecho encontra-se em aberto. Em primeiro lugar, o ataque à autonomia decisória não é exclusividade do desenvolvimento dos mercados e pertence à própria Administração Pública $e$ arranjos organizacionais em ambulatórios e hospitais. O próprio planejamento em saúde se ocupou de canalizar ou estruturar um leque amplo de decisões médicas. Os sistemas de remuneração do ato médico no setor público, do código 7 do Inamps às AIHs, também representaram iniciativas no sentido de decompor e medir as decisões clínicas e cirúrgicas, para distribuir incentivos.

No planejamento público em saúde e nos mercados diversos controles foram obtidos sobre a prática médica e seus resultados são desiguais. Podemos dizer que sucessos foram alcançados por programas de saúde e equipes multidisciplinares, nos quais a prática clínica foi potencializada pelo enfoque epidemiológico em benefício de clientes e usuários.

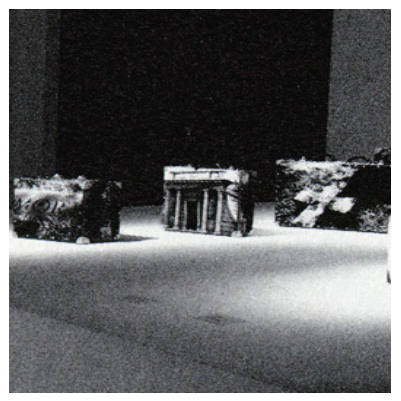
Por outro lado, a profunda e acelerada diferenciação da clínica em especialidades e sub-especialidades geram uma separação no interior das redes sanitárias e grandes organizações (como os hospitais) entre as atividades capturadas pela burocracia gerencial e aquelas dotadas de maior autonomia e status organizacional.

Por fim, o movimento de reestruturação da clínica e da cirurgia em mercados, como no debate em torno do managed care, sofre mais claramente os reflexos da demanda por qualidade por parte dos beneficiários de planos e seguros de saúde, assim como da competição entre organizações em mercados dinâmicos. Neste sentido, inovações como gatekeepers (cujos similares no setor público podem ser identificados nas equipes de saúde da família brasileiras ou nos general practitioners britânicos) convivem com a demanda crescente por tecnologias e especialistas de elevado tempo de formação e de alta intensidade de trabalho.

As conquistas da Biomedicina sobre o prolongamento e a qualidade da 
vida (e suas promessas em termos de transplantes, clonagens, angiogêneses, por exemplo) geram pressões políticas sobre a democratização do acesso pelos sistemas públicos e entre as comunidades que rateiam os seguros de saúde na qualidade de beneficiários. Desta forma, os médicos tendem a preservar amplas atividades fora do controle intensivo das burocracias públicas e organizacionais privadas como resultado da demanda informada por qualidade. $\mathrm{O}$ ataque à autonomia tende a ser incompleto.

Este quadro representa um dos motivos relevantes para a minha crença sobre os abusos praticados pelos médicos e empresas serem compensados essencialmente pela disseminação de informações e estratégias que equilibrem a assimetria do encontro médico-cliente/usuário/beneficiário. As informações devem ser promovidas por organizações não-governamentais, grupos de defesa dos consumidores, agências governamentais, universidades e clientelas organizadas. Neste caso, nos situamos dentro de soluções voltadas à qualidade das escolhas individuais e este é um ponto de convergência, apesar dos termos distintos da discussão, que observo com o instigante artigo de Merhy.

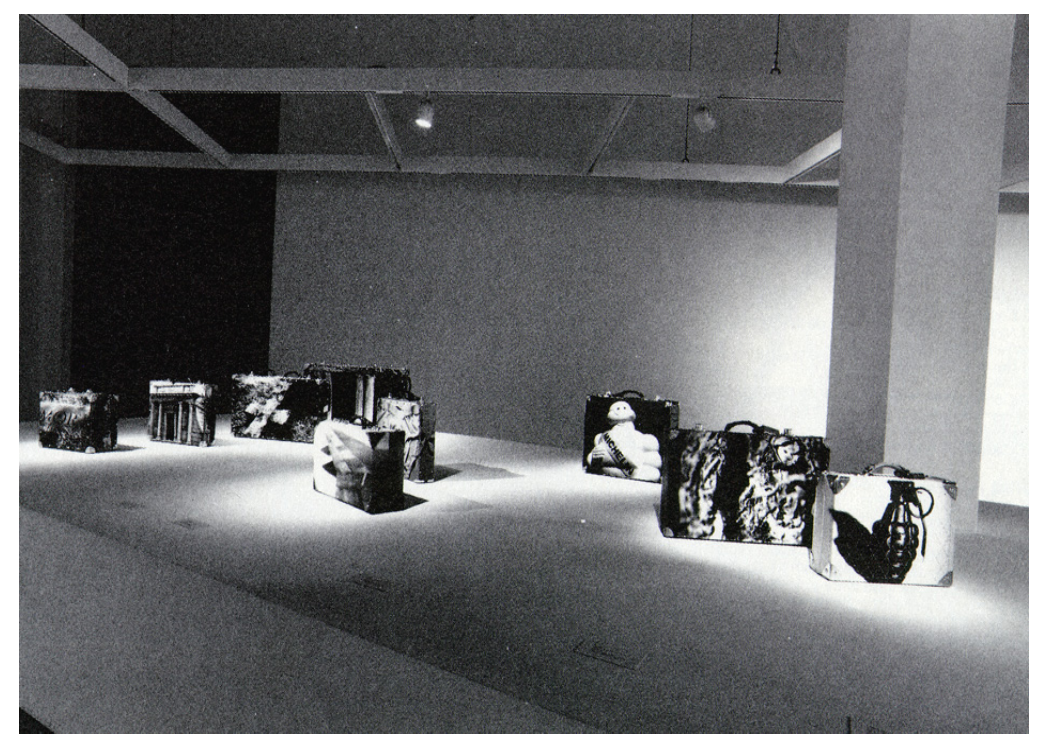

ALAN BELCHER, Instalação da exposição na Power Plant, Toronto. $20^{a}$ Bienal Internacional de São Paulo 